\title{
Поправка к статье „Экспериментальное исследование спектра флуоресценции атомов цезия в присутствии буферного газа“ (том 124 № 1 2018)
}

() В.Г. Давыдов, В.Н. Кулясов

В заголовке статьи допущена ошибка в аффилиации автора В.Г. Давыдова

Следует читать:

Экспериментальное исследование спектра флуоресценции атомов цезия в присутствии буферного газа

(C) В.Г. Давыдов ${ }^{1,2}$, В.Н. Кулясов ${ }^{1}$

${ }^{1}$ Государственный оптический институт им. С.И. Вавилова, 199053 Санкт-Петербург, Россия

${ }^{2}$ Санкт-Петербургский государственный университет, 199034 Санкт-Петербург, Россия 